\title{
PERKEMBANGAN ILMU PENGETAHUAN DAN LAHIRNYA MADRASAH SEBAGAI LEMBAGA PENDIDIKAN FORMAL
}

\author{
Oleh: Muzakkir*
}

\begin{abstract}
Science is essentially from Allah swt. He teaches and educates people through His selected person, His Messenger, with perfect teachings for all human beings in order that they can recognize himself and his God. The development of science is in line with the development of thinking and analytical skills of mankind. The transformation of knowledge to different people with different language is mainly by the process of translation. Trans-formation of knowledge, especially Islamic education began in a form of khalaqah in mosques or teachers' houses, then developed to be formal education known as madrasah.
\end{abstract}

KEYWORDS: Ilmu pengetahuan, penerjemahan, pendidikan formal

MUHAMMAD SAW. setelah beberapa tahun bertahannus, ${ }^{1}$ diberi instruksi dan petunjuk oleh Allah swt. melalui perantaraan Malaikat Jibril berupa wahyu Al-Qur'an tentang apa yang harus Beliau lakukan, baik terhadap dirinya sendiri maupun terhadap umatnya.

Allah swt. telah mendidik dan mempersiapkan Muhammad Saw. untuk melaksanakan tugas sebagai Rasul-Nya secara sempurna. Dengan potensi fitrahnya yang luar biasa dia sanggup secara sadar beradaptasi dengan lingkungannya tanpa terbawa arus budaya atau larut dalam tradisi masyarakat jahiliyah saat itu.

Ketika itulah dia yakin benar bahwa masyarakatnya telah sesat dari jalan yang benar. Kebenaran yang sesungguhnya ialah Allah, Khalik seluruh alam, tidak ada Tuhan selain Dia.

Muhammad Saw. menerima wahyu yang pertama Q.S. al-'Alaq (96): 1-5 dan disusul wahyu yang kedua dalam Q.S. al-Mudatstsir (74): 1-7. Dalam kedua wahyu yang mula-mula turun itu dapat diambil kesimpulan bahwa pendidikan dalam Islam terdiri dari empat macam, ${ }^{2}$ yaitu:

*Magister Pendidikan Islam lulusan Program Pascasarjana Institut Agama Islam Negeri Alauddin Makassar ini adalah dosen tetap pada Fakultas Tarbiyah dan Keguruan UIN Alauddin Makassar. 
1. Pendidikan keagamaan, yaitu hendaklah membaca dengan nama Allah semata-mata, jangan dipersekutukan dengan nama berhala, sebab Tuhan itu Maha Besar dan Maha Pemurah.

2. Pendidikan 'aqliyah dan ilmiah, yaitu mempelajari kejadian manusia dari segumpal darah dan kejadian alam semesta. Alam akan menjadi pelajaran bagi orang-orang yang mau menyelidiki dan membahasnya. Untuk mempelajari hal-hal itu haruslah dengan banyak membaca dan menyelidiki serta memakai pena untuk mencatat.

3. Pendidikan akhlak al-karimah, yaitu si pendidik hendaklah suka memberi/mengajar tanpa mengharapkan balasan dari orang yang menerima pemberian/pengajarannya. Mendidik karena Allah semata dan mengharapkan keridhaan-Nya. Begitu juga si pendidik harus berhati sabar dan tabah dalam melakukan tugasnya.

4. Pendidikan jasmani (kesehatan), yaitu mementingkan kebersihan, bersih pakaian, bersih badan, dan bersih tempat kediaman. Terutama si pendidik harus bersih pakaian, suci hati dan baik budi pekertinya, supaya menjadi contoh dan teladan bagi anak-anak didiknya.

Pendidikan dan pengajaran yang dilaksanakan oleh Nabi Saw. di Makkah adalah tentang pendidikan keagamaan dan akhlak, anjuran kepada manusia supaya mempergunakan akal pikirannya memperhatikan kejadian manusia, hewan, tumbuh-tumbuhan dan alam semesta, sebagai arahan mengembangkan pendidikan akliah dan ilmiah.

Rasulullah Saw. adalah pendidik pertama dan terutama dalam dunia pendidikan Islam. Proses transformasi ilmu pengetahuan, internalisasi nilai-nilai spiritualisme dan bimbingan emosional yang dilakukannya dapat dikatakan sebagai mu'jizat luar biasa, yang manusia apa dan di mana pun tidak dapat melakukan hal yang sama. ${ }^{3}$

Nabi Saw. telah mendidik umatnya secara bertahap. Beliau mulai dari keluarga dekatnya; istrinya Khadijah diajak beriman dan menerima petunjuk-petunjuk Allah, kemudian anak pamannya 'Ali bin Abi Thalib, dan Zaid bin Harisah (seorang pembantu rumah tangganya, yang kemudian dijadikan anak angkatnya). Dilanjutkan kepada sahabat karibnya Abū Bakar ash-Shiddī , yang segera menerima ajakannya. Secara berangsur-angsur kepada keluarga dekat suku Quraisy.

Orang-orang yang mula-mula masuk Islam (as-sābiqūna al-awwalūn) yang secara langsung diajar dan dididik oleh Nabi saw. menjadi muslim yang siap menerima dan melaksanakan perintah Allah yang akan diturunkan kepada beliau.

Bahan/materi pendidikan, kemudian diturunkan oleh Allah swt. kepada Nabi saw. secara berangsur-angsur, sedikit demi sedikit, dan di- 
iringi dengan penjelasan-penjelasan dan contoh-contoh cara pelaksanaannya.

Pada tahun ke-12 Nubuwah (621 M), ketika musim haji tiba, datanglah 12 orang laki-laki dari Jatsrib (Madinah) lalu bai'ah (bersetia) dengan Nabi serta memeluk agama Islam. Kemudian Nabi mengutus Mush'ab Umair pergi bersama mereka ke Jatsrib untuk membacakan Al-Qur'an dan mengajarkan agama Islam kepada penduduk di sana. Inilah guru agama pertama yang diutus Nabi ke daerah di luar kota Makkah.

\section{PERKEMBANGAN ILMU PENGETAHUAN MELALUI KEGIATAN PENERJEMAHAN PADA AWAL PENDIDIKAN ISLAM}

Pusat kegiatan pendidikan pada tahap awal diselenggarakan secara sembunyi-sembunyi di rumah Arqam bin Abi Arqam. ${ }^{5}$ Rumah Arqam itulah tempat pendidikan Islam yang pertama dalam sejarah pendidikan Islam. Di sanalah Nabi mengajarkan dasar-dasar/pokok-pokok agama Islam kepada sahabat-sahabatnya. Di rumah Arqam lah terbentuk jama'ah Islamiyah yang pertama. ${ }^{6}$

Penyampaian ajaran Islam secara sembunyi-sembunyi didasarkan pada perintah Allah dalam Al-Qur'an surah asy-Syu'arā (26): 213-216, yang berlangsung sekitar 3 tahun, kemudian Nabi diperintahkan menyampaikan pendidikannya secara terbuka dalam kurun waktu sekitar 20 tahun dengan sebaik-baiknya.

Pada masa khilafah Bani Umayyah, perkembangan di bidang keilmuan, baik ilmu-ilmu keagamaan maupun ilmu-ilmu aqliyah, tidaklah menonjol. Penerjemahan buku-buku dari bahasa non-Arab pun tampak tidak memiliki arti signifikan. ${ }^{7}$ Dapat diduga, hal itu disebabkan karena kesibukan para khalifah dalam menyelenggarakan pemerintahan yang mapan di samping terjadinya pembebasan wilayah-wilayah baru ke pangkuan Islam.

Kegiatan keilmuan rasional belum familiar bagi masyarakat Arab saat itu. Tradisi Arab yang gemar akan syair lebih menonjol dibandingkan tradisi ilmiah rasional. Namun demikian, ada catatan mengenai upaya perintisan keilmuan, yaitu bahwa ilmu pengobatan dan kimia merupakan salah satu disiplin ilmu yang paling awal dikembangkan. Khalid (w. 708) sebagai orang Islam pertama yang menerjemahkan buku-buku berbahasa Yunani dan Koptik tentang kimia, kedokteran, dan astrologi. 8

Penerjemahan karya-karya pemikiran Yunani telah menyemarakkan dunia pendidikan Islam di masa Klasik. Pendidikan Islam di masa Klasik, dapat dikategorikan maju bahkan dianggap telah mencapai masa keemasan sepanjang sejarah. Sejak penerjemahan karya-karya pemikiran Yunani, 
pendidikan Islam mengalami kemajuan pesat baik dalam materi pengajarannya (kurikulum), maupun lembaga pendidikan. ${ }^{9}$ Dengan kurikulum yang terfokus pada bidang keagamaan, madrasah justru dapat diterima luas di kalangan masyarakat, karena materi pokok yang diajarkan madrasah pada saat itu seperti fikih, dianggap memenuhi kebutuhan masyarakat dan dapat diberikan pada anggota masyarakat dalam segala tingkatan umur. Di samping itu, para pengajar madrasah adalah para ulama yang notabene merupakan panutan masyarakat serta pembela kepentingan mereka dan memiliki kedudukan khusus dalam pemerintah-an. ${ }^{10}$

Pada tahun (378 H) Khalifah al-Azis, khalifah keempat dari Daulah Fatimiyah mengubah fungsi Jami' al-Azhar menjadi Universitas al-Azhar, yang banyak menarik perhatian para mahasiswa dari seluruh penjuru dunia Islam. ${ }^{11}$

Ciri khas pendidikan pada masa pemerintahan Muawiyyah, adalah pendidikan pemerintahan, pendidikan kedisiplinan, dan pendidikan kemiliteran. ${ }^{12}$

\section{PERKEMBANGAN ILMU PENGETAHUAN}

\section{Perkembangan Ilmu Naqli}

Ilmu naqli adalah ilmu yang bersumber dari naqli (Al-Qur'an dan Hadits), yaitu ilmu yang berhubungan dengan agama Islam. Ilmu ini mulai dikembangkan sekitar 200 tahun sesudah hijriyah. Ilmu-ilmu yang tergabung di dalamnya antara lain: Ilmu Tafsir, Ilmu Hadits, Ilmu Kalam, Ilmu Tasawuf, Ilmu Bahasa, Ilmu Fiqih.

\section{Perkembangan Ilmu Aqli}

Ilmu aqli adalah ilmu yang didasarkan kepada pemikiran (rasio). Ilmu yang tergolong dalam ilmu ini kebanyakan dikenal umat Islam berasal dari terjemahan asing: dari Yunani, Persia, atau India. Yang termasuk ilmu ini antara lain kedokteran, kimia, filsafat, fisika, tata negara, musik, astronomi, dan ilmu hitung. Untuk mendapatkan ilmu ini mereka mendatangi kota-kota pusat pengembangannya.

\section{Metode Pendidikan/Pengajaran}

Pada masa Dinasti Abbasiyah metode pendidikan/pengajaran yang digunakan dapat dikelompokkan menjadi tiga macam, yaitu lisan, hafalan, dan tulisan.

1. Metode lisan, berupa dikte, ceramah, qira'ah, dan diskusi.

2. Metode menghafal, merupakan ciri umum pendidikan pada masa ini. Murid-murid harus membaca secara berulang-ulang pelajarannya se- 
hingga pelajaran tersebut melekat pada benak mereka, dan pada proses selanjutnya, murid akan mengeluarkan kembali dan mengkontekstualisasikan pelajaran yang dihafalnya.

3. Metode tulisan, dianggap metode yang paling penting pada masa ini. Metode tulisan adalah penyalinan karya-karya ulama. Dalam menyalin buku-buku terjadi proses intelektualisasi hingga tingkat penguasaan ilmu murid semakin meningkat. ${ }^{13}$

\section{Materi Pendidikan}

Materi pendidikan pada masa daulat Abbasiyah, selain materi pelajaran yang bersifat wajib (ijbari) bagi setiap murid juga ada materi yang bersifat pilihan (ikhtiari). Hal ini tampaknya sangat berbeda dengan materi pendidikan dasar pada masa sekarang. Di saat sekarang ini materi pendidikan tingkat dasar dan menengah semuanya adalah materi wajib, tidak ada materi pilihan. Materi pilihan baru ada pada tingkat perguruan tinggi.

Materi pelajaran yang bersifat wajib (ijbari) ialah: Al-Qur'an, shalat, do'a, sedikit ilmu nahwu, membaca, dan menulis. Mata pelajaran pilihan (ikhtiari) ialah: berhitung, semua ilmu nahwu, syair-syair, dan tarikh Arab/Riwayat. ${ }^{14}$

\section{Sistem Pengajaran}

Pada masa Abbasiyah pengajaran dilaksanakan secara berhalaqah (duduk bersila berkeliling), anak-anak menulis hanya memakai batu tulis dan kertas yang bersahaja. Sistem ini digunakan baik di lembaga pendidikan tingkat dasar maupun di tingkat perguruan tinggi.

Usaha penerjemahan (750-900 M) dari bahasa Yunani ke bahasa Arab sebenarnya sudah dimulai sejak zaman Umawiyah, tetapi usaha besarbesaran dimulai sejak khalifah al-Mansur dari Abbasiyah. Pusat penting tempat terjemahan adalah Yunde Sahpur. ${ }^{15}$ Meskipun Baghdad yang dikenal sebagai kota besar dan menjadi ibu kota daulah Abbasiyah, namun Yunde Sahpur tetap sebagai kota ilmu pengetahuan pertama dalam Islam.

Popularitas daulah Abbasiyah mencapai puncaknya di zaman khalifah Harun al-Rasyid yang memerintah selama 23 tahun (786-809 M). Putera Harun al-Rasyid yang bernama al-Amin memerintah selama 4 tahun 8 bulan, kemudian dilanjutkan oleh saudaranya al-Ma'mun yang memerintah selama 20 tahun (813-833 M). Al-Ma'mun dikenal sebagai khalifah yang sangat cinta kepada ilmu. Pada masa pemerintahannya, penerjemahan buku-buku asing digalakkan. Untuk menerjemahkan bukubuku Yunani, ia menggaji penerjemah-penerjemah dari golongan Kristen dan penganut agama lain yang ahli. Ia juga banyak mendirikan sekolah, 
salah satu karya besarnya yang terpenting adalah pembangunan Bait alHikmah pusat penerjemahan yang berfungsi sebagai perguruan tinggi dengan perpustakaan yang besar. Pada masa al-Makmun inilah, Baghdad mulai menjadi pusat kebudayaan dan ilmu pengetahuan. ${ }^{16}$ Kekayaan negara banyak dimanfaatkan Harun al-Rasyid untuk keperluan sosial. Rumah sakit, lembaga pendidikan dokter, dan farmasi didirikan. Pada masa inilah negara Islam mencapai puncaknya sebagai negara terkuat dan tak tertandingi.

Gerakan membangun ilmu secara besar-besaran dirintis oleh khalifah Ja'far al-Manshur. ${ }^{17}$ Setelah ia mendirikan kota Bagdad (144 H/762 M) dan menjadikannya sebagai ibu kota negara maka ia mengajak para ulama dan para ahli dari berbagai daerah untuk datang tinggal di Bagdad. Ia merangsang usaha pembukuan ilmu agama, seperti fikih, tafsir, tauhid, hadits, atau ilmu lain seperti ilmu bahasa dan ilmu sejarah. Akan tetapi yang lebih mendapat perhatian adalah penerjemahan buku-buku yang berasal dari luar. ${ }^{18}$ Perkembangan ilmu pada masa ini meliputi dua macam yakni perkembangan ilmu naqli dan perkembangan ilmu aqli.

Pada zaman al-Ma'mun kemauan usaha penerjemahan mencapai puncaknya dengan didirikannya "Sekolah Tinggi Terjemah" di Baghdad dilengkapi dengan lembaga ilmu yang disebut Bait al-Hikmah suatu lembaga yang dilengkapi dengan observatorium, perpustakaan, dan badan penerjemah. ${ }^{19}$

Sejak penerjemahan buku-buku Yunani, kurikulum dalam pendidikan Islam mengalami kemajuan pesat. Lembaga-lembaga pendidikan yang sebelumnya hanya mengajarkan pengetahuan agama, mulai mengajarkan ilmu pengetahuan umum seperti: matematika, fisika, dan kedokteran.

Pendidikan Islam pada masa pertumbuhan dan perkembagannya, juga pada masa-masa berikutnya mempunyai dua sasaran, yaitu generasi muda (sebagai generasi penerus) dan masyarakat yang belum menerima ajaran Islam. Penyampaian ajaran Islam kepada masyarakat dan usaha internalisasinya lazim disebut sebagai dakwah Islami. Sedangkan sasaran yang pertama, yaitu untuk pewarisan ajaran Islam kepada generasi penerus disebut sebagai pendidikan Islam. ${ }^{4}$

Istilah pendidikan Islam dapat dipahami dari tiga sudut pandang, yaitu: (a)pendidikan agama Islam (b) pendidikan dalam Islam (c) pendidikan menurut Islam. Dalam kerangka akademik, ketiga sudut pandang itu harus dibedakan dengan tegas, karena ketiganya akan melahirkan disiplin ilmu sendiri-sendiri. Pendidikan agama Islam menunjuk kepada proses operasional dalam usaha pendidikan ajaran-ajaran agama Islam. Pendekatan ini kelak menjadi bahan kajian dalam "Ilmu Pendidikan Islam Teoretis". 
Pendidikan dalam Islam bersifat sosio-historis, dan menjadi bahan kajian dalam "Sejarah Pendidikan Islam". Sedangkan pendidikan menurut Islam bersifat normatif, dan menjadi bahan kajian dalam "Filsafat Pendidikan Islam".

Sistem pendidikan Islam di masa klasik tidak dikenal sekolah tingkat menengah. Yang ada hanya lembaga pendidikan tingkat dasar dan lembaga pendidikan tingkat tinggi. ${ }^{20}$ Seperti halnya sekolah tingkat dasar, pada sekolah tingkat tinggi juga diajarkan ilmu pengetahuan umum, bahkan diajarkan filsafat setelah terjadinya kontak dengan peradaban Yunani.

Setelah menguasai karya-karya Hellenisme, semangat ilmuan-ilmuan Islam untuk mengadakan pengamatan, penelitian, dan pengkajian berkembang pesat, sehingga mereka berhasil menemukan teori-teori baru di bidang ilmu pengetahuan dan filsafat yang belum terjadi pada era sebelumnya. Pemikiran Hellenisme yang mereka transmisikan dalam karyakarya pemikiran Islam bukanlah sekedar terjemahan atau jiplakan, tetapi merupakan karya asli umat Islam. ${ }^{21}$

Kehadiran Islam di pentas dunia telah membawa perubahan besar. Perubahan besar itu mencakup segala aspek: politik, ekonomi, sosial, pendidikan, intelektual, kebudayaan dan peradaban. Kedigdayaan Islam di masa lampau kini menjadi sejarah. Aspek pendidikan Islam telah mengukir prestasi yang gemilang dan disaksikan oleh pecinta ilmu di berbagai belahan dunia.

\section{PERKEMBANGAN LEMBAGA PENDIDIKAN ISLAM SAMPAI MUN- CULNYA MADRASAH MENJADI PENDIDIKAN FORMAL}

Berbicara mengenai lembaga pendidikan Islam tidak bisa dilepaskan dari pandangan atau konsep Islam itu sendiri mengenai pendidikan. Pendidikan Islam merupakan wujud dari pengaruh berbagai kebudayaan atau peradaban yang pernah ada dalam sejarah. Namun demikian para ahli pendidikan Islam biasanya berpandangan bahwa pendidikan Islam memiliki karakter dan tujuannya sendiri yang khas, karena ia didasarkan kepada tujuan yang bersifat metafisis-transendental, yaitu untuk mencapai keridaan Allah swt. di dunia dan akhirat.

Kendatipun ilmu pengetahuan menempati kedudukan yang tinggi dan terhormat di dalam konsep pendidikan Islam, tetapi ilmu pengetahuan itu bukanlah tujuan dalam dirinya sendiri. Tujuan ilmu pengetahuan digariskan berdasarkan tuntunan wahyu, sebab ilmu pengetahuan itu sendiri berasal dari wahyu (baca: Allah swt.). Ilmu pengetahuan memperoleh maknanya yang hakiki jika ia mampu menghantarkan manusia (penuntut ilmu) kepada tujuannya yang hakiki pula, yaitu kedekatan (taqarrub) ke- 
pada Allah, dan kebaikan kepada sesama manusia (akhlāq al- karimah). Karena itu akhlak menempati posisi penting, bahkan sentral dalam pendidikan Islam. Hal ini merupakan kelanjutan logis dari pernyataan Nabi saw. sendiri bahwa beliau diutus membawa agama Islam ke dunia ini untuk menyempurnaan keluhuran akhlak budi manusia.

Jika demikian, pendidikan dalam Islam merupakan sarana untuk menuju ke arah penyempurnaan akhlak mulia. Dengan kata lain, pendidikan dalam Islam adalah berfungsi untuk mencapai keluhuran akhlak budi, sedangkan lembaga pendidikan adalah aspek material untuk menjalankan fungsi tersebut. Pendidikan adalah substansinya, sedangkan lembaga pendidikan adalah institusi atau pranatanya yang telah terbentuk secara ajek dan mapan di tengah-tengah masyarakat.

Masjid yang telah difungsikan ganda sejak zaman Nabi Saw. di masa kerajaan Mughal Badsyahi merupakan bangunan yang terindah dan terletak di sebelah barat benteng Lahore. Masjid yang dibangun selain sebagai tempat ibadah, juga berfungsi sebagai tempat belajar agama bagi masyarakat. Dalam hal pendidikan, kerajaan Mughal terlihat memberikan perhatian yang besar.

Proses transformasi dari masjid ke madrasah, berkembang beberapa teori yang secara sepintas berbeda satu sama lain. Di antaranya teori yang dikemukakan George Makdisi dalam Maksum, ia berkesimpulan bahwa perpindahan lembaga pendidikan Islam dari masjid ke madrasah terjadi secara tidak langsung, tetapi melalui tahapan perantara, yaitu masjid-khan. ${ }^{22}$

Dalam kajiannya yang lebih fokus pada madrasah Nizhāmiyyah periode pertengahan di Baghdad, Makdisi mengajukan teori bahwa asal muasal pertumbuhan madrasah merupakan hasil tiga tahap: tahap masjid, tahap masjid-khan, dan tahap madrasah.23 Tahap masjid berlangsung terutama pada abad-abad kedelapan dan kesembilan. Masjid yang dimaksud di sini adalah masjid yang di samping untuk tempat shalat berjama'ah juga untuk majlis taklim (pendidikan). Di Baghdad pada masa itu terdapat beribu-ribu masjid yang berfungsi sebagai tempat pendidikan.

Tahap kedua adalah lembaga masjid-khan, yaitu masjid yang dilengkapi dengan bangunan khan (asrama, pemondokan) yang masih bergandengan dengan masjid. Masjid-khan menyediakan tempat penginapan yang cukup representatif bagi para pelajar yang datang dari berbagai kota. Tahap ini mencapai perkembangan pesat pada abad ke-10.

Setelah dua tahap di atas barulah muncul madrasah yang khusus diperuntukkan sebagai lembaga pendidikan. Perkembangan madrasah dalam polanya yang utuh dan konkrit dipelopori oleh Nizhām al-Mulk. Namun, tidaklah berarti bahwa Nizhām al-Mulk adalah orang pertama 
yang mendirikan madrasah dalam sejarah Islam abad pertama. Yang menjadikan ia berjasa dalam pengembangan madrasah adalah bahwa ia mempopulerkan pendidikan madrasah bersamaan dengan reputasinya sebagai wazir dalam kekuasaan Saljuk.

Tokoh pendidik yang juga memberikan perhatian tinggi terhadap sejarah kelembagaan madrasah adalah Ahmad Syalabi. Menurutnya perkembangan dari masjid ke madrasah terjadi secara langsung, tidak memakai lembaga perantara. ${ }^{24}$ Perkembangan madrasah dapat dikatakan sebagai konsekuensi logis dari semakin ramainya kegiatan pengajian di masjid yang fungsi utamanya adalah tempat ibadah. Untuk tidak mengganggu ketenangan dalam beribadah di masjid, maka kegiatan pendidikan dibuatkan tempat khusus yang dikenal dengan nama madrasah.

Kata madrasah dalam bahasa Arab berarti tempat atau wahana untuk mengenyam proses pembelajaran. Dalam bahasa Indonesia madrasah disebut dengan sekolah yang berarti bangunan atau lembaga untuk belajar dan memberi pengajaran.

Berdasarkan pengertian di atas, maka jelaslah bahwa madrasah adalah wadah atau tempat belajar ilmu-imu keislaman dan ilmu pengetahuan keahlian lainnya yang berkembang pada zamannya. Dengan demikian, dapat disimpulkan bahwa istilah madrasah bersumber dari Islam itu sendiri.

Madrasah mulai didirikan dan berkembang pada abad ke-5 $\mathrm{H}$ atau abad ke-10 atau ke-11 M. Pada masa itu ajaran agama Islam telah berkembang secara luas dalam berbagai macam bidang ilmu pengetahuan, dengan berbagai macam mazhab atau pemikirannya. Pembagian bidang ilmu pengetahuan tersebut bukan saja meliputi ilmu-ilmu yang berhubungan dengan Al-Qur'an dan hadis, seperti ilmu-ilmu Al-Qur'an, hadits, fikih, ilmu kalam, maupun ilmu tasawwuf tetapi juga bidang-bidang filsafat, astronomi, kedokteran, matematika dan berbagai bidang ilmu-ilmu alam dan kemasyarakatan.

Aliran-aliran yang timbul akibat perkembangan tersebut saling berebutan pengaruh di kalangan umat Islam, dan berusaha mengembangkan aliran dan mazhabnya masing-masing. Maka terbentuklah madrasahmadrasah dalam pengertian kelompok pikiran, mazhab, atau aliran. Itulah sebabnya sebahagian besar madrasah didirikan pada masa itu dihubungkan dengan nama-nama mazhab yang masyhur pada masanya, misalnya madrasah Syafi' iyah, Hanafiyah, Malikiyah dan Hambaliyah.

Berdasarkan keterangan di atas, jelaslah bahwa penggunaan istilah madrasah, sebagai lembaga pendidikan Islam maupun sebagai aliran atau mazhab bukanlah sejak awal perkembangan Islam, tetapi muncul setelah Islam berkembang luas dan telah menerima pengaruh dari luar, sehingga 
terjadilah perkembangan berbagai macam bidang ilmu pengetahuan dengan berbagai macam aliran dan mazhabnya.

Pada awal perkembangan Islam, terdapat dua jenis lembaga pendidikan dan pengajaran, yaitu $k u t t a \bar{b}{ }^{25}$ yang mengajarkan cara menulis dan membaca Al-Qur'an, serta dasar-dasar pokok ajaran Islam kepada anakanak yang merupakan pendidikan tingkat dasar. Sedangkan masjid dijadikan sebagai tingkat pendidikan lanjutan pada masa itu yang hanya diikuti oleh orang-orang dewasa. Dari masjid-masjid, lahirlah ulama-ulama besar yang ahli dalam berbagai ilmu pengetahuan Islam, dan dari sini pulalah timbulnya aliran-aliran atau mazhab-mazhab dalam berbagai ilmu pengetahuan, yang waktu itu dikenal dengan istilah madrasah. Kegiatan para ulama dalam mengembangkan ajaran Islam di tengah-tengah masyarakat Islam maju dengan pesatnya, bahkan dari satu periode ke periode berikutnya semakin meningkat.

Selain kemajuan intelektual Islam, lembaga pendidikan Islam pun mengalami perkembangan pesat setelah terjadinya kontak dengan Helenisme. ${ }^{26}$ Lembaga-lembaga pendidikan Islam seperti kuttāb, masjid, khalaqah dan majlis (pada tempat-tempat tertentu, seperti di rumah ulama), mengalami perubahan karasteristik, bahkan muncul bentuk lembaga pendidikan baru, yang menimbulkan dualisme lembaga pendidikan Islam, yaitu ada lembaga pendidikan Islam yang terbuka pada pengetahuan umum dan ada yang khusus mengajarkan pengetahuan agama.

Menurut Charles Michail Stanton dalam Hanun Asrohah bahwa lembaga pendidikan Islam di masa Klasik ada dua macam, yaitu lembaga pendidikan Islam formal dan informal. ${ }^{27}$ Kriteria yang digunakan untuk membedakan kedua bentuk lembaga tersebut adalah hubungan lembaga pendidikan dengan negara yang berbentuk teokrasi. Lembaga pendidikan formal adalah lembaga pendidikan yang didirikan oleh negara untuk mempersiapkan pemuda-pemuda Islam agar menguasai pengetahuan agama dan berperan dalam agama, atau menjadi tenaga birokrasi, atau pegawai pemerintahan. Pengelolaan administrasinya ditangani oleh penguasa. Kurikululumnya tentang ilmu agama atau ilmu naqliyah. Sedangkan lembaga pendidikan informal menawarkan pelajaran-pelajaran pengetahuan umum, termasuk filsafat.

Dalam sumber yang sama, George Makdisi membagi lembaga pendidikan Islam (sebelumnya lahirnya madrasah) menjadi dua tipe, yaitu lembaga pendidikan yang eksklusif (tertutup) terhadap pengetahuan umum dan lembaga pendidikan yang inklusif (terbuka) terhadap pengetahuan umum. ${ }^{28}$ 
Untuk menampung kegiatan khalaqah yang semakin banyak, sejalan dengan meningkatnya jumlah pelajaran dan bidang ilmu pengetahuan yang diajarkan, maka dibangunlah ruangan-ruangan khusus untuk kegiatan khalaqah atau pengajian tersebut di sekitar masjid. Di samping itu dibangun pula asrama khusus untuk guru dan pelajar, sebagai tempat tinggal dan tempat kegiatan belajar mengajar setiap hari secara teratur, yang disebut dengan zawiyah atau madrasah yang pada mulanya hanya dibangun di sekitar masjid, tetapi pada perkembangan selanjutnya banyak dibangun secara pribadi atau swadaya masyarakat.

Dalam sejarah Islam dikenal banyak sekali tempat dan pusat pendidikan dengan jenis, tingkat dan sifatnya yang khas. Ahmad syalabi menyebutkan tempat-tempat itu sebagai berikut: Lembaga pendidikan dasar (al-Kuttāb); b. Lembaga pendidikan masjid (al-Masjid), c. Kedai pedagang kitab (ㅂawānit al-Warāqiīn); d. tempat tinggal para sarjana (Manāzil al'Ulamā); e. sanggar seni dan sastra (al-shalunat al-adabiyah); f. perpustakaan (dar al-kutub wa dar al'ilm; dan g. lembaga pendidikan sekolah (Madrāsah), al-Qushur, al-Badiyah. Dia membagi institusi-institusi pendidikan Islam menjadi dua kelompok, yaitu kelompok sebelum madrasah, dan sesudah madrasah. Madrasah dianggap sebagai tonggak baru dalam penyelenggaraan pendidikan Islam. Madrasah yang dimaksud adalah yang dibangun oleh Nizhām al-Mulk tahun $459 \mathrm{H}$.

Madrasah sebagai lembaga pendidikan dalam bentuk pendidikan formal sudah dikenal sejak awal abad ke-11 atau ke-12 M, (abad ke-5 atau ke-6 H), yaitu sejak dikenal adanya Madrasah Nizhāmiyah yang didirikan di Baghdad oleh Nizhām al-Mulk, seorang Nazir dari Dinasti Saljuk. ${ }^{29}$ Pendirian madrasah ini telah memperkaya khasanah lembaga pendidikan di lingkungan masyarakat Islam, karena pada masa sebelumnya masyarakat Islam hanya mengenal pendidikan tradisional yang diselenggarakan di masjid-masjid dan dār al-kuttāb.

Hasan al-'Āl menyimpulkan bahwa "madrasah adalah institusi yang timbul pada abad keempat Hijriyah" dan menganggapnya sebagai "Era baru dari tahapan perkembangan institusi pendidikan Islam. ${ }^{30}$

Era baru ditandai dengan adanya ketentuan-ketentuan yang lebih jelas yang berkaitan dengan komponen-komponen pendidikan dan pada keterlibatan pemerintah dalam pengelolaan madrasah. Madrasah Nizhāmiyah merupakan lembaga pendidikan resmi dan pemerintah terlibat dalam menetapkan tujuan-tujuannya, kurikulum, memilih guru, dan memberikan dana yang teratur untuk pengelolaan madrasah. ${ }^{31}$ Ahmad Syalabi menjadikan pendirian madrasah Nizhāmiyah sebagai pembatas untuk membedakannya dengan era pendidikan Islam sebelumnya. 
Makdisi menyetujui adanya "peraturan-peraturan" (nizhām) sebagai kelebihan madrasah, tetapi ia menganggap madrasah -khususnya madrasah Nizhāmiyah- sebagai madrasah perseorangan. Dia menilai Nizhām al-Mulk adalah seorang pribadi yang mengelola madrasah untuk tujuantujuan sendiri. Jadi, tidak ada keterlibatan pemerintah secara formal.

Dari kajian tentang pertumbuhan dan perkembangan madrasah Nizhāmiyyah dapat ditemukan tiga tujuan utamanya: pertama, menyebarkan pemikiran Sunni untuk menghadapi tantangan pemikiran Syi'ah; kedua, menyediakan guru-guru Sunni yang cakap untuk mengajarkan mazhab Sunni dan menyebarkannya ke tempat-tempat lain; ketiga, membentuk kelompok pekerja Sunni untuk berpartisipasi dalam menjalankan pemerintahan, memimpin kantornya, khususnya di bidang peradilan dan manajemen. ${ }^{32}$

Pada hakikatnya timbulnya madrasah-madrasah di dunia Islam merupakan usaha pengembangan dan penyempurnaan kegiatan proses belajar mengajar dalam upaya untuk menampung pertumbuhan dan perkembangan ilmu pengetahuan dan jumlah pelajar yang semakin meningkat dan bertambah setiap tahun ajaran.

Di timur tengah instutusi madrasah berkembang untuk menyelenggarakan pendidikan keislaman tingkat lanjut (advance/tinggi), yaitu melayani mereka yang masih haus ilmu sesudah sekian lama menimbanya dengan belajar di masjid-masjid dan atau dār al-kuttāb. Dengan demikian pertumbuhan madrasah sepenuhnya merupakan perkembangan lanjut dan alamiah dari dinamika internal yang tumbuh dari dalam masyarakat Islam sendiri.

Model madrasah tidak sama dengan masjid dan kuttāb. Madrasah merupakan pengembangan dari masjid. Akibat motivasi belajar umat Islam yang sangat tinggi, masjid-masjid penuh dengan khalaqah-khalaqah, suara guru yang menjelaskan pelajaran dan atau diskusi-diskusi bahkan perdebatan dalam proses belajar mengajar, sehingga menimbulkan kebisingan yang mengganggu orang yang shalat atau berzikir, maka lahirlah bentuk lembaga pendidikan baru. Perkembangan bentuk lembaga ini melalui tiga tahap; yaitu dari masjid ke masjid-khan, kemudian menjadi madrasah. ${ }^{33}$

Keberadaan madrasah di Indonesia, boleh dikatakan sebagai fenomena baru dari lembaga pendidikan Islam yang ada. Kehadirannya sekitar permulaan abad ke-20 M. Namun dalam penyelenggaraan pendidikan dan pengajarannya masih belum punya keseragaman antara daerah yang satu dengan daerah yang lain, terutama sekali menyangkut kurikulum dan rencana pelajaran. Usaha ke arah penyatuan dan penyeragaman sistem 
tersebut, baru dirintis sekitar tahun 1950 setelah Indonesia merdeka. Dan pada perkembangannya madrasah terbagi dalam jenjang-jenjang pendidikan; Madrasah Ibtidaiyah, Madrasah Tsanawiyah dan Madrasah Aliyah.

\section{KESIMPULAN}

Berdasarkan uraian di atas, dapat disimpulkan bahwa:

1. Rasulullah Saw. sebagai pendidik pertama dan terutama dalam dunia pendidikan Islam telah mendidik sahabat-sahabatnya dengan dasardasar ilmu pengetahuan, baik ilmu naqli maupun ilmu aqli. Ilmu pengetahuan mengalami perkembangan pesat melalui kegiatan penerjemahan buku-buku Yunani Kuno ke dalam Bahasa Arab dan selanjutnya diterjemahkan ke bahasa yang lain.

2. Madrasah lahir sebagai lembaga pendidikan formal dari perkembangan kegiatan ilmiah yang awalnya dilaksanakan di masjid, kuttāb, $\underline{\text { Hawānit }}$ al-Warāqī̄n, Manāzil al-'Ulamā, dan lain-lain. Madrasah dinyatakan sebagai lembaga pendidikan formal setelah pemerintah terlibat mengatur pengelolaannya, seperti penentuan kurikulum, penetapan gurugurunya, penyediaan dana dan fasilitas lainnya.

\section{CATATAN AKHIR:}

1. Bertahannus, yaitu suatu cara menjauhkan diri dari keramaian orang, berkhalwat dan mendekatkan diri kepada Tuhan dengan bertapa dan berdo'a mengharapkan diberi rezeki dan pengetahuan. Haekal, Sejarah Hidup Muhammad, jilid I, terjemahan Ali Audah, Jakarta: Tintamas, 1972, h. 81.

2. Mahmud Yunus, Sejarah Pendidikan Islam, Cet. V, Jakarta: Hidakarya Agung, 1989, h. 5 - 6.

3. Samsu Nizar, Sejarah Pendidikan Islam: Menelusuri Jejak Sejarah Pendidikan Era Rasulullah Sampai Indonesia, Cet. II, Jakarta: Kencana, 2008, h. 1.

4. Zuhairini, dkk., Sejarah Pendidikan Islam, Cet. III, Jakarta: Bumi Aksara, 1992, h. 70 .

5. Haekal. op. cit., h. 84 .

6. Mahmud Yunus, op. cit., h. 7.

7. Didin Saefuddin Buchori, Sejarah Politik Islam, Cet. I, Jakarta: Pustaka Intermasa, 2009, h. 72.

8. Ibid.

9. Hanun Asrohah, Sejarah Pendidikan Islam, Cet. I; Jakarta: Logos, 1999, h. 43.

10. Abuddin Nata, Sejarah Pendidikan Islam: Pada Periode Klasik dan Pertengahan, Cet. I, Jakarta: RajaGrafindo Persada, 2004, h. 178-179.

11. Ibid., h. 152. 
12. Bahaking Rama, Sejarah Pendidikan dan Peradaban Islam dari Masa Umayah Hingga Kemerdekaan Indonesia, Cet. I, Yogyakarta: Cakrawala Publishing, 2010, h. 17.

13. Hanun Asrohah, op. cit., h. 77-79.

14. Mahmud Yunus, Sejarah op. cit., h. 50.

15. Musyrifah Sunanto, Sejarah Islam Klasik: Perkembangan Ilmu Pengetahuan Islam, Cet. III, Jakarta: Kencana, 2007, h. 79.

16. W. Montgomery Watt, Kejayaan Islam: Kajian Kritis dari Tokoh Orientalis, terjemahan, Yogyakarta:Tiara Wanaca,1990, h. 68.

17. Ali Mustafa al-Ghurabi, Tarikh al-Firaq al-Islamiyah, Kairo;Mathba'ah Ali Shahih,1959, h.137.

18. Ahmad Amin, Dhuha al-Islam, Jilid I, Kairo: Maktabah al-Nahdah,1972, h. 272.

19. Musyrifah Sunanto, op. cit., h. 79.

20. Hanun Asrohah, op. cit., h. 58.

21. Ibid., h. 45.

22. Maksum, Madrasah: Sejarah dan Perkembangannya, Cet. I, Jakarta: Logos, 1999, h. 56.

23. Ibid., h. 57.

24. Ahmad Syalabi, History of Muslim Education, Beirut: Dār al-Kasysyaf, 1954, h. 258.

25. Dalam Ensiklopedia Islam dijelaskan bahwa Kuttāb adalah sejenis tempat belajar yang mula-mula lahir di dunia Islam. Pada awalnya kuttāb berfungsi sebagai tempat memberikan pelajaran menulis dan membaca bagi anak-anak. Kuttāb sebenarnya sudah ada di negeri arab sebelum datangnya Islam, tetapi belum dikenal. Di antara penduduk Mekah yang mula-mula belajar menulis huruf Arab di kuttāb ini ialah Sofyan bin Umayyah bin Abdul Syams dan Abu Qais bin Abdul Manaf bin Zuhroh bin Kilab.

26. Helenisme adalah suatu paham atau pemikiran yang berasal dari kebudayaan Yunani Kuno. Dewasa ini Helenisme digunakan untuk menyebut segala bentuk peniruan atau adabtasi atas unsur-unsur kebudayaan Yunani Kuno, misalnya dalam kerangka pemikiran, ide, adat, maupun penggunaan istilah dari khasanah bahasa Yunani Kuno. Pengaruh kebudayaan Yunani disebarluaskan melalui berbagai bidang kehidupan, seperti ilmu pengetahuan, seni, agama, hukum dan filsafat. Pada masa itu dunia ilmu pengetahuan berkembang dengan munculnya penemuan-penemuan baru. Tim Penyusun, Ensiklopedi Nasional Indonesia, jilid VI, Cet. I, Jakarta: Cipta Adi Pustaka, 1989, h. 379.

27. Hanun Asrohah, op cit., h. 46.

28. Ibid., h. 47.

29. Abdul Rahman Shaleh, Madrasah dan Pendidikan Anak Bangsa: Visi, Misi dan Aksi, Cet. I, Jakarta: RajaGrafindo Persada, 2004, h. 11 - 12.

30. Maksum, op. cit., h. 53.

31. Ibid., h. 61.

32. Ibid., h. 61-62.

33. Hanun Asrohah, op. cit., h. 99. 


\section{DAFTAR PUSTAKA}

Amin, Ah̆mad, Dhuhā al-Islām, Jilid I, Kairo: Maktabah al-Nahdah, 1972.

Asrohah, Hanun, Sejarah Pendidikan Islam, Cet. I, Jakarta: Logos Wacana Ilmu, 1999.

Buchori, Didin Saefuddin, Sejarah Politik Islam, Cet. I, Jakarta: Pustaka Intermasa, 2009.

Al-Ghurābi, Ali Musthafa, Tarikh al-Firāq al-Islāmiyah, Kairo: Mathba'ah Ali Shahih, 1959.

Haekal, Sejarah Hidup Muhammad Saw., Jilid I, terjemahan Ali Audah, Jakarta: Tintamas, 1972.

Maksum, Madrasah: Sejarah dan Perkembangannya, Cet. I, Jakarta: Logos, 1999.

Nata, Abuddin, Sejarah Pendidikan Islam: Pada Periode Klasik dan Pertengahan, Cet. I, Jakarta: RajaGrafindo Persada, 2004.

Nizar, Samsu, Sejarah Pendidikan Islam: Menelusuri Jejak Sejarah Pendidikan Era Rasulullah Sampai Indonesia, Cet. II, Jakarta: Kencana, 2008.

Rama, Bahaking, Sejarah Pendidikan dan Peradaban Islam dari Masa Umayah Hingga Kemerdekaan Indonesia, Cet. I, Yogyakarta: Cakrawala Publishing, 2010.

Shaleh, Abdul Rahman, Madrasah dan Pendidikan Anak Bangsa: Visi, Misi dan Aksi, Cet. I; Jakarta: RajaGrafindo Persada, 2004.

Sunanto, Musyrifah, Sejarah Islam Klasik: Perkembangan Ilmu Pengetahuan Islam, Cet. III, Jakarta: Kencana, 2007.

Syalabi, Ahmad, History of Muslim Education, Beirut: Dār al-Kasysyaf, 1954.

Tim Penyusun, Ensiklopedi Nasional Indonesia, Jilid VI, Cet. I, Jakarta: Cipta Adi Pustaka, 1989.

Watt, W. Montgomery, Kejayaan Islam: Kajian Kritis dari Tokoh Orientalis, (terjemahan) Yogyakarta: Tiara Wanaca, 1990.

Yunus, Mahmud, Sejarah Pendidikan Islam, Cet. V, Jakarta: Hidakarya Agung, 1989.

Zuhairini, dkk., Sejarah Pendidikan Islam, Cet. III, Jakarta: Bumi Aksara, 1992. 